\title{
28. INSOLUBLE ORGANIC MATTER AND BITUMENS IN LEG 44 SAMPLES
}

\author{
R.D. McIver and M.A. Rogers, Exxon Production Research Company, Houston, Texas
}

\begin{abstract}
Investigation of 18 core samples from Holes 388A, 391A, and 391C, Leg 44 of the Deep Sea Drilling Project, shows low-to-moderate amounts of organic carbon in Miocene and Upper Cretaceous sediments of the outer continental rise of the eastern United States and of the Blake-Bahama Basin. The organic matter is partly amorphous and algal in nature, and the extractable bitumens range up to $987 \mathrm{ppm}$ in the 10 Tertiary samples and up to $476 \mathrm{ppm}$ in the Cretaceous samples. Only a small fraction (from 0 to 18 per cent) of the bitumen is hydrocarbon which indicates the sediments have undergone virtually no thermal maturation (catagenesis); this is also indicated by the low kerogen alteration indices ( 17 of the 18 are $1+$ or less).

The hydrocarbon fractions of the bitumens are unusual. The saturates are virtually all paraffins and one- and two-ring naphthenes, and the aromatics have relatively large quantities of indenes, and chrysenes and phenanthrenes with different ones in different samples.

Details of mass spectrometric determinations, both molecular and carbon isotopic, show that the five significant extracts are not products of two of the lubricants used aboard the Glomar Challenger. The gas chromatograms of the saturate hydrocarbon fractions also support this interpretation.

Five canned mud samples were very low in hydrocarbon gas (all less than $275 \mathrm{ppm}$ ); but this is probably the product of poor sampling techniques or leaking seals, and does not reflect the actual gas content of the samples.
\end{abstract}

\section{INTRODUCTION}

As a continuing program, samples are taken for organic geochemical studies; some are canned and some frozen shortly after collection. In this particular case, a suite of such samples from Leg 44 was returned to the Deep Sea Drilling repository at Scripps Institute of Oceanography where organic geochemists made selections in December 1975. On the basis of organic carbon contents of available frozen samples, and their appearance (darkness), we selected 18 samples for investigation of the amount and nature of insoluble organic matter and the molecular and isotopic mass spectrometric analyses of the hydrocarbon portion of the soluble bitumen. Five canned cuttings samples were also made available to us for determination of hydrocarbon gas. The samples are identified in Table 1.

We subjected the cores to standard analyses (McIver, 1974). First the samples were cleaned by removal of a thin film from the outside surfaces. They were then dried in a dust-free hood. The dried sample was pulverized and homogenized. A small aliquot was removed from each for organic carbon determination by standard acid digestion (to remove carbonates) and combustion methods. The kerogen of another aliquot of each was visually described by microscopy after destruction of carbonate and silicate minerals by $\mathrm{HCl}$ and HF treatments, respectively. The remaining portions were extracted by organic solvents to remove the soluble bitumens, which were separated by liquidsolid chromatography into asphaltenes, NSO- compounds, aromatic hydrocarbons, and saturated hydrocarbons. Results of these investigations are shown in Table 1.

The saturate and aromatic fractions of the five samples with enough hydrocarbon to analyze were then further analyzed for the distributions of their molecular types by analytical mass spectrometry, and their carbon isotope composition by isotope ratio mass spectrometry (by previously reported techniques described in McIver, 1974).

Results of these determinations are shown in Table 2. Portions of the saturate fractions were also introduced into a gas chromatograph to determine the $n$-paraffin distribution. These chromatograms are shown in Figures 1a-g.

To check whether the small quantities of hydrocarbon were indigenous to the sediments or might be contaminants from shipboard lubricants, we submitted samples of the Challenger's pipe dope and wire line grease for liquid-solid chromatographic separation and the hydrocarbon fractions for analytical mass spectrometry and carbon isotope spectrometry. Results of this check are shown in Table 2. Portions of the saturate fractions of these lubricants were also run by gas chromatography, and their chromatograms are also shown in Figures if and g.

\section{Hole 388A}

\section{RESULTS AND INTERPRETATION}

All four of these Miocene claystones had more than the minimum organic carbon $(0.4 \%)$ generally thought 
TABLE 1

Leg 44 Samples Collected for Organic Geochemical Studies-Chromatographic and Kerogen Data Extractable Bitumen

\begin{tabular}{|c|c|c|c|c|c|c|c|c|c|}
\hline \multirow[b]{2}{*}{$\begin{array}{c}\text { Sample } \\
\text { (Interval in } \mathrm{cm} \text { ) }\end{array}$} & \multirow[b]{2}{*}{$\begin{array}{l}\text { Age and Sedi- } \\
\text { ment Type }\end{array}$} & \multirow[b]{2}{*}{$\begin{array}{l}\text { Organic } \\
\text { Carbon }\end{array}$} & \multicolumn{5}{|c|}{ Extractable Bitumen } & \multicolumn{2}{|l|}{ Kerogen } \\
\hline & & & $\begin{array}{l}\text { Total }^{\mathrm{a}} \\
(\mathrm{ppm})\end{array}$ & $\begin{array}{l}\text { Asphal- } \\
\text { tenes }\end{array}$ & $\mathrm{NSO}$ & Sulfur & $\frac{\mathrm{C}_{15^{+} \mathrm{HC}}}{(\mathrm{ppm})}$ & Types $^{\mathrm{b}}$ & $\begin{array}{l}\text { Alteration } \\
\text { Index }\end{array}$ \\
\hline $388 \mathrm{~A}-5-0,20-40$ & Miocene clay & 0.43 & 161 & 141 & - & - & $<5$ & Woody: H-C; Amorphous & $1+$ \\
\hline $388 \mathrm{~A}-7-3,17-30$ & Miocene clay & 0.46 & 435 & 318 & 84 & 2 & 31 & Amorphous-Woody; H-C & $1+$ \\
\hline $388 \mathrm{~A}-7-4,30-54$ & Miocene clay & 0.44 & 219 & 146 & 35 & 17 & 21 & Amorphous (Algal): W; H & $1+$ \\
\hline $388 \mathrm{~A}-11-0,0-20$ & Miocene clay & 0.57 & 239 & 131 & 51 & 13 & 44 & Amorphous (Algal); H; W & $1+$ \\
\hline $391 \mathrm{~A}-3-4,0-28$ & $\begin{array}{l}\text { Miocene calcar- } \\
\text { eous clay }\end{array}$ & 0.17 & 386 & 378 & - & - & $<5$ & Amorphous (Algal); $\mathrm{H}$; W-C & $1+$ \\
\hline $391 \mathrm{~A}-4-3,0-8$ & $\begin{array}{l}\text { Miocene marly } \\
\text { chalk }\end{array}$ & 0.25 & 627 & 600 & - & - & $<5$ & Amorphous (Algal); H; W-C & $1+$ \\
\hline $391-5-0,23-40$ & $\begin{array}{l}\text { Miocene marly } \\
\text { chalk }\end{array}$ & 0.42 & 516 & 414 & 38 & 36 & 28 & Amorphous; H; W-C & $1+$ \\
\hline $391 \mathrm{~A}-9-0,0-50$ & $\begin{array}{l}\text { Miocene marly } \\
\text { chalk }\end{array}$ & 0.34 & 360 & 337 & - & - & $<5$ & Amorphous; H; W-C & $1+$ \\
\hline $391 \mathrm{~A}-13-0,20-35$ & $\begin{array}{l}\text { Miocene calcar- } \\
\text { eous mudstone }\end{array}$ & 1.63 & 987 & 957 & - & - & $<5$ & Amorphous (Algal); H-W; C & $1+$ \\
\hline $391 \mathrm{~A}-20-2,20-40$ & $\begin{array}{l}\text { Miocene calcar- } \\
\text { eous claystone }\end{array}$ & 0.85 & 356 & 234 & 89 & 5 & 29 & Amorphous (Algal); H-W;C & $1+$ \\
\hline $391 C-6-3,100-120$ & $\begin{array}{l}\text { Cretaceous clay- } \\
\text { stone }\end{array}$ & 0.66 & 361 & 341 & - & - & $<5$ & Amorphous-Woody; C; H & $1+$ \\
\hline $391 C-7-2,110-125$ & $\begin{array}{l}\text { Cretaceous clay- } \\
\text { stone }\end{array}$ & 1.39 & 244 & 217 & - & - & $<5$ & Amorphous-Woody: C; H & $1+$ \\
\hline $391 C-8-2,115-143$ & $\begin{array}{l}\text { Cretaceous clay- } \\
\text { stone }\end{array}$ & 0.94 & 160 & 125 & - & - & $<5$ & Amorphous (Algal); W; C & $1+$ \\
\hline $391 C-9-3,42-92$ & $\begin{array}{l}\text { Cretaceous clay- } \\
\text { stone }\end{array}$ & 1.75 & 211 & 167 & - & - & $<5$ & Amorphous; W; H-C & $1+$ \\
\hline $391 C-16-1,120-130$ & $\begin{array}{l}\text { Cretaceous shaly } \\
\text { limestone }\end{array}$ & 0.88 & 476 & 443 & - & - & $<5$ & Amorphous; W; H-C & $1+$ \\
\hline $391 C-26-3,110-113$ & $\begin{array}{l}\text { Cretaceous shaly } \\
\text { limestone }\end{array}$ & 0.51 & 335 & 297 & - & - & $<5$ & Amorphous; W; H & $1+$ \\
\hline $391 C-40-2,10-24$ & $\begin{array}{l}\text { Cretaceous shaly } \\
\text { limestone }\end{array}$ & 0.08 & 330 & 319 & - & - & $<5$ & Amorphous; H; W & $1+$ \\
\hline $391 C-52-2,10-20$ & $\begin{array}{l}\text { Cretaceous clay- } \\
\text { stone }\end{array}$ & 0.39 & 115 & 98 & - & - & $<5$ & Woody; Am-C; H & $2+$ \\
\hline
\end{tabular}

\section{Canned Mud}

388A-9-5 148-150

399A-9-6, 145-150

$390-4-2,126-135$

$391 \mathrm{C}-12-4,125-150$

391C-14-3, 125-138
Hydrocarbon Gas

$$
\begin{gathered}
\mathrm{tr} \\
290 \mathrm{ppm} \\
621 \mathrm{ppm} \\
\text { tr } \\
\mathrm{tr}
\end{gathered}
$$

\footnotetext{
${ }^{a}$ Total may be more than the apparent combined weight of separate fractions because of handling losses and fractions reported only when above about $5 \mathrm{ppm}$.

${ }^{\mathrm{b}}$ Abbreviations: $\mathrm{H}=$ Herbaceous $; \mathrm{C}=$ Coaly $; \mathrm{W}=$ Woody $; \mathrm{Am}=$ Amorphous.
}

necessary for sediment to have petroleum source potential, and in three of the four, the organic matter is predominantly the amorphous type, also generally thought to be one of the more "oily" types. However, the small hydrocarbon fraction of the total bitumen and the low alteration index indicate that the sediment has undergone virtually no thermal maturation, i.e., catagenesis, which, in more deeply buried or older rocks, produces hydrocarbons from the kerogen, NSO's, and asphaltenes. The carbon isotope data suggest the organic matter is marine in origin, but the analytical mass spectrometer shows the aromatic hydrocarbons are unusual. The prominence of one compound type (indenes in Core 7, Section 3 and tetrahydrophenanthrene in Core 7, Section 4) often is found in very immature sediments.

\section{Site 391}

The organic carbon contents of the six Miocene samples, in Hole 391A at this site, are more erratic than in the sediments of the same age from Hole 388A, perhaps because the rocks are more calcareous. Five of the six exceed the requirements generally thought necessary for sediments to be potential petroleum source rocks $(0.2 \%$ for carbonates and $0.4 \%$ for clastics). The mudstone (Core 13, Section 0) in particular is rich. However, as in the sediments in Hole $388 \mathrm{~A}$, these Miocene sediments also have very low hydrocarbon contents and low alteration indices. They too are very immature. This is further supported by the mass spectra of the aromatic hydrocarbon fractions of two of these cores; in one indenes predominate, in the other, naphthalenes.

Eight Cretaceous samples from Hole 391C vary widely both in organic carbon contents and lithology. The first four, all claystones, have enough organic carbon to classify them as potential petroleum source rocks, and the predominance of amorphous types suggests an oily nature, but the very low $\mathrm{C}_{15}+$ hydrocarbon content and the low alteration indices indicate virtually no catagenic action. 

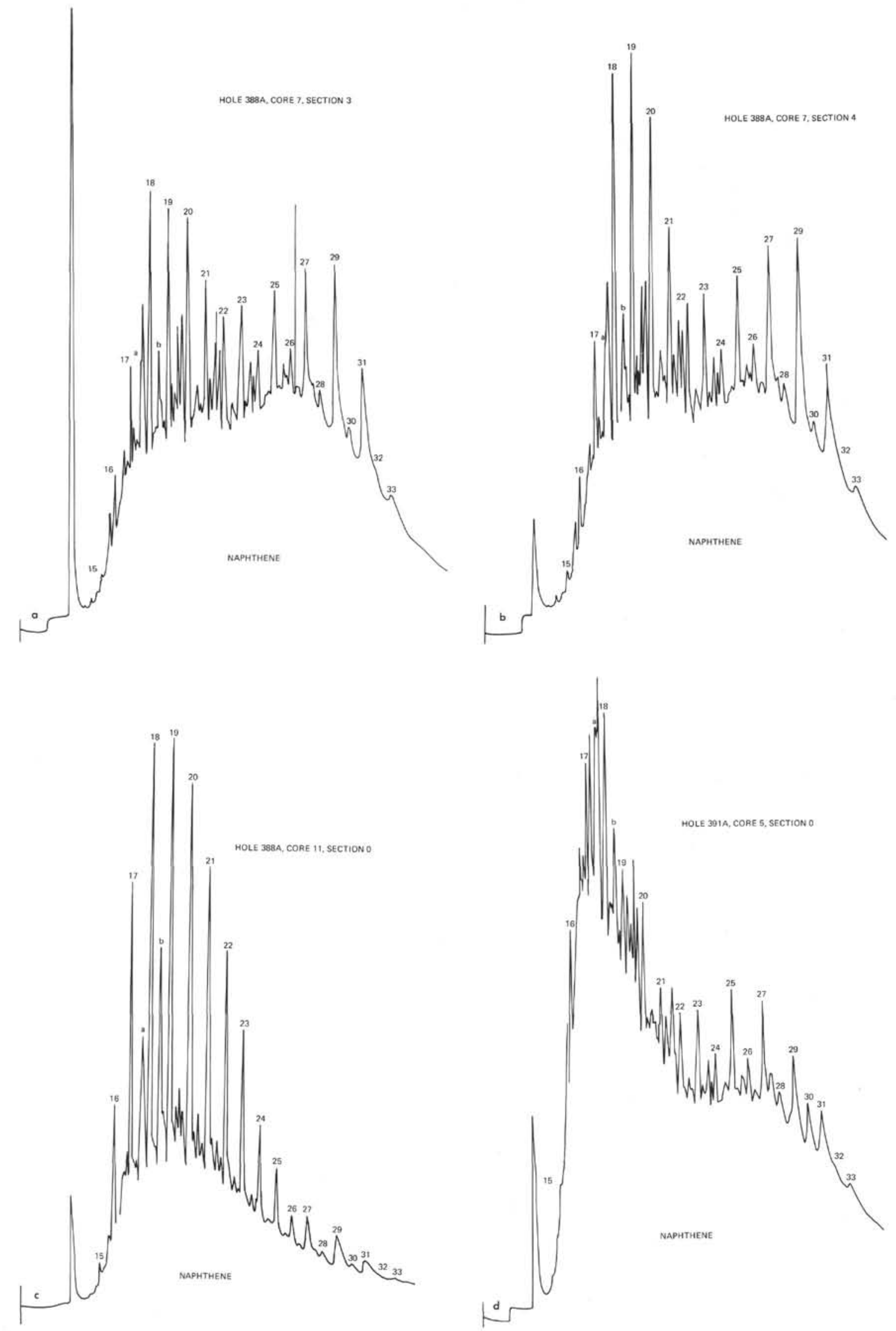

Figure 1a-d. Gas chromatograms of the saturate hydrocarbon fractions. 

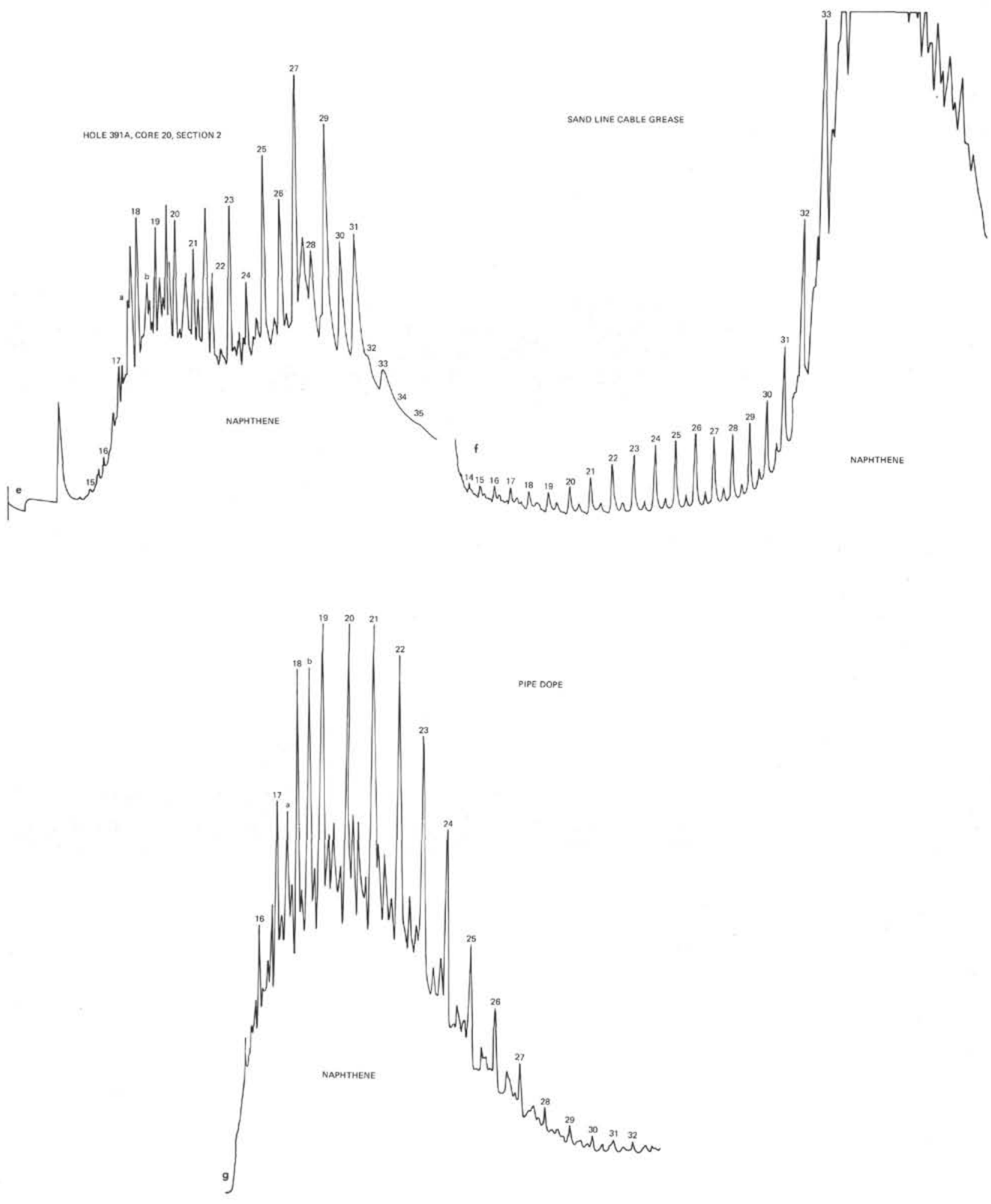

Figure 1e-g. Gas chromatograms of the saturate hydrocarbon fractions. 
TABLE 2

Mass Spectrometric Characterization of Leg 44 Sediment Hydrocarbons

\begin{tabular}{|c|c|c|c|c|c|c|c|}
\hline & $388 \mathrm{~A}-7-3$ & $388 \mathrm{~A}-7-4$ & $388 \mathrm{~A}-11-0$ & $391 \mathrm{~A}-5-0$ & $391 \mathrm{~A}-20-2$ & $\begin{array}{l}\text { Pipe } \\
\text { Dope }\end{array}$ & $\begin{array}{l}\text { Cable } \\
\text { Grease }\end{array}$ \\
\hline \multicolumn{8}{|l|}{ Saturates (normalized) $(\%)$} \\
\hline Paraffins & 42.9 & 50.8 & 41.3 & 46.6 & 34.0 & 27.1 & 30.6 \\
\hline 1-ring Naphthenes & 35.8 & 22.4 & 26.0 & 24.3 & 28.2 & 18.4 & 22.6 \\
\hline 2-ring Naphthenes & 11.4 & 12.9 & 15.5 & 12.4 & 9.9 & 23.1 & 16.1 \\
\hline 3-ring Naphthenes & 5.2 & 7.8 & 9.5 & 8.3 & 16.9 & 17.1 & 12.4 \\
\hline 4-ring Naphthenes & 3.2 & 2.8 & 4.4 & 2.5 & 3.8 & 8.5 & 7.1 \\
\hline 5-ring Naphthenes & 0.8 & 1.4 & 1.5 & 2.4 & 2.6 & 3.0 & 3.9 \\
\hline 6-ring Naphthenes & 0.7 & 1.9 & 1.9 & 3.4 & 4.7 & 2.8 & 7.3 \\
\hline \multicolumn{8}{|l|}{ Aromatics (normalized) $(\%)$} \\
\hline Benzenes & 0.1 & 2.9 & 12.3 & 1.5 & 3.0 & 15.8 & 19.0 \\
\hline Indanes & 7.2 & 3.5 & 6.8 & 8.5 & 3.7 & 8.1 & 10.0 \\
\hline Indenes & 59.2 & 25.1 & 13.4 & 37.5 & 14.3 & 7.6 & 9.8 \\
\hline Naphthalenes & 6.2 & 12.5 & 5.8 & 14.8 & 31.5 & 2.7 & 26.1 \\
\hline Tetrahydrophenanthrene & 3.3 & 39.7 & 8.6 & 5.1 & 5.1 & 6.7 & 7.4 \\
\hline Dihydrophene & 0.5 & 0.8 & 11.6 & 2.3 & 3.8 & 12.9 & 8.7 \\
\hline Phenanthrene & 0.0 & 0.0 & 13.5 & 2.2 & 18.3 & 4.7 & 0.0 \\
\hline Pyrenes & 0.0 & 0.0 & 0.0 & 0.0 & 0.0 & 4.3 & 0.0 \\
\hline Chrysenes & 20.0 & 13.8 & 5.7 & 20.6 & 7.0 & 5.7 & 0.0 \\
\hline Benzothiophenes & 0.0 & 0.0 & 4.6 & 0.0 & 0.7 & 9.7 & 6.1 \\
\hline Dibenzothiophene & 1.6 & 1.8 & 17.7 & 7.5 & 12.6 & 21.8 & 12.8 \\
\hline Thiophenanthrophene & 1.9 & 0.0 & 0.0 & 0.0 & 0.0 & 0.0 & 0.0 \\
\hline \multicolumn{8}{|l|}{$\begin{array}{l}\text { Carbon-Isotope Composition } \\
\% \mathrm{C}^{13} / \mathrm{C}^{12} \mathrm{vs} \text { PDB }\end{array}$} \\
\hline Saturate Fraction & -28.3 & NA & -28.2 & 27.9 & -28.5 & -27.2 & -29.5 \\
\hline Aromatic Fraction & -27.3 & NA & -24.8 & -25.9 & -22.6 & -27.0 & -29.7 \\
\hline
\end{tabular}

The next two, shaly limestones, also are embryonic sources, but the bottom two, a limestone and a claystone, fall below minimum organic carbon levels for sources.

\section{CONTAMINATION}

The mass spectra of the hydrocarbons are unusual, particularly those of the aromatic fractions. They have relatively large quantities of indenes, chrysenes, and phenanthrenes, with different ones predominant in different samples. The same fractions of wire-line grease and pipe dope do not match any of the extracts overall or in detail. These show generally more benzenes. Moreover, the carbon isotope ratios are different, particularly in the difference between the saturate and aromatic fractions of one sample. The ratios of the two fractions for the shipboard lubricants are virtually identical (within $0.2 \%$ ). They are different for the extracts (from 1.0 to $5.9 \%$ difference). The gas chromatograms of the saturate fractions also show the "extracts" are not from the two most likely contaminants. The cable grease is much higher in molecular weight; the pipe dope is in about the same molecular weight range, but is different. It has relatively less of the hydrocarbons in the $\mathrm{C}_{24}$ to $\mathrm{C}_{33}$ ranges and the ratios of pristane (a) and phytane (b) to normal $\mathrm{C}_{17}$ and $\mathrm{C}_{18}$ paraffins are much lower in the extracts than in the lubricant.

\section{CONCLUSIONS}

Holes at Sites 388 and 391 off the eastern continental margin of the United States only penetrated sediments above the catagenic zone of hydrocarbon generation. The type and amount of organic matter show that the sediments are richer in organic matter than average abyssal sediments, but it is virtually unaltered.

\section{REFERENCE}

McIver, R.D., 1974. Evidence of migrating hydrocarbons in Deep Sea Drilling Project cores: Am. Assoc. Petrol. Geol.Bull, v. 58, p. 1263-1271. 